\title{
Genetic Variability, Heritability, Correlation Analysis, Genetic advance, and Principal Component Analysis of Grain Yield and Yield Related Traits of Quality Protein Maize (Zea mays L) Inbred lines Adapted to Mid-altitude Agroecology of Ethiopia
}

\author{
Lemi Yadesa ${ }^{1}$, Beyene Abebe $^{2}$ and Zelalem Tafa ${ }^{3}$ \\ ${ }^{1,2}$ EIAR-Bako National Maize Research Centre, Addis Ababa, Ethiopia \\ ${ }^{3}$ EIAR-Holeta Agricultural Research Centre, Addis Ababa, Ethiopia
}

\begin{tabular}{|c|c|}
\hline $\begin{array}{c}\text { Article History } \\
\text { Received: } 18.11 .2021 \\
\text { Accepted: } 24.12 .2021 \\
\text { Published: } 09.02 .2022 \\
\\
\text { Journal homepage: } \\
\text { https://www.easpublisher.com }\end{array}$ & 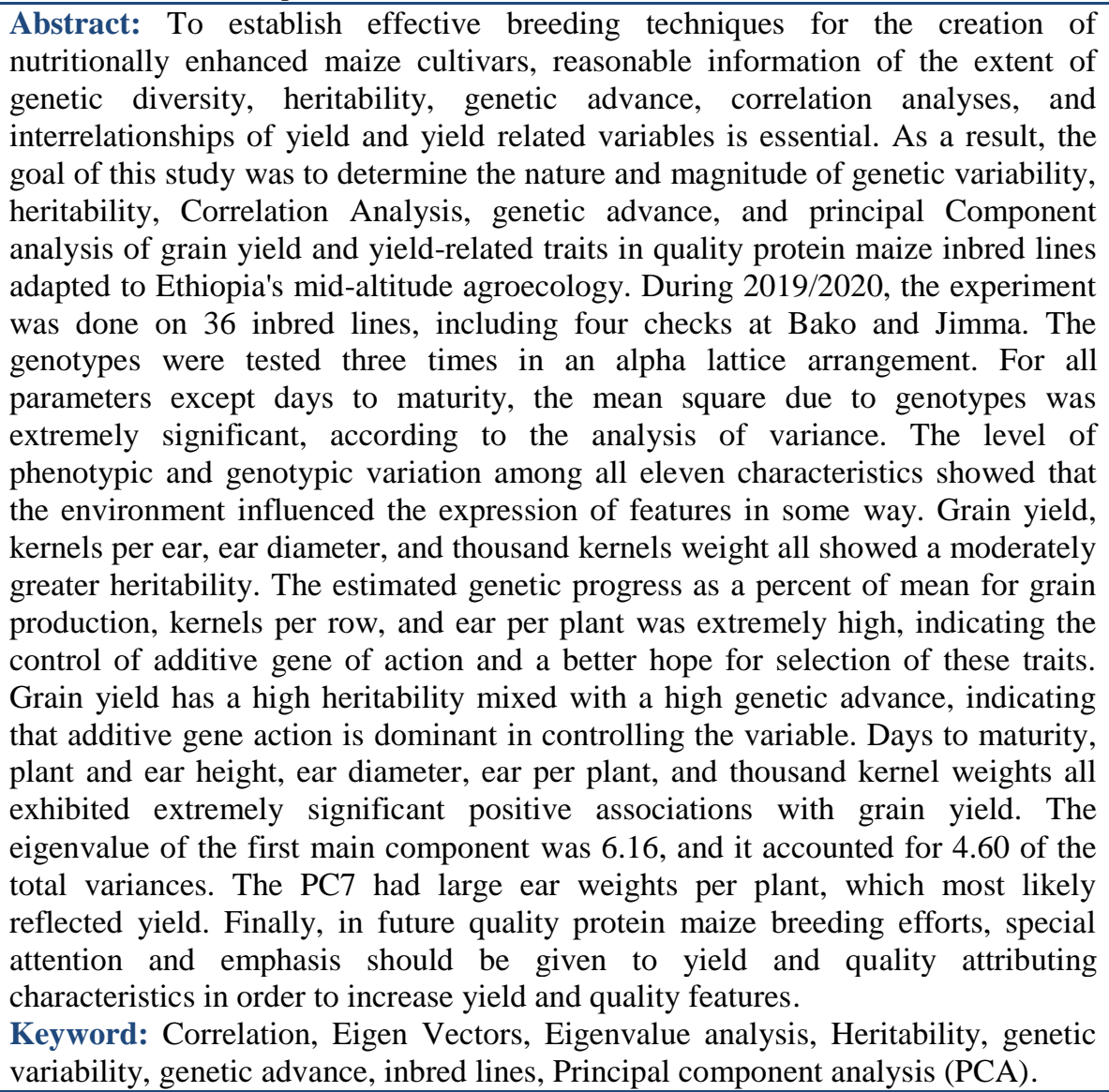 \\
\hline
\end{tabular}

Copyright ( 12022 The Author(s): This is an open-access article distributed under the terms of the Creative Commons Attribution 4.0 International License (CC BY-NC 4.0) which permits unrestricted use, distribution, and reproduction in any medium for non-commercial use provided the original author and source are credited.

\section{INTRODUCTION}

Maize is a major source of food and feed for livestock and poultry for a big portion of the world's population (Prasanna 2012). In terms of production volume, area coverage, and household consumption, maize is one of the five major cereals (along with wheat, teff, barley, and sorghum) (Tsedeke et al., 2015). Maize feeds around 300 million individuals in SubSaharan Africa who are food insecure (La Rovere et al. 2010). According to current data, it is the most important staple food crop in Sub-Saharan Africa, supporting the livelihoods of more than 1.2 billion people (Makore et al, 2021). Maize enhancement for yield potential is the focus of numerous genomics and breeding efforts throughout the world, as it is a critical component of global food security (Katragadda et al, 2020). As a result, to solve the problem of feed insecurity, a quick rise in maize yield is a top goal for reducing hunger and poverty. 
Maize yields in poor nations are substantially lower than in developed countries. According to FAO (2019), Africa's average maize yields are less than 2.01 tons/ha, while West Africa's yields are less than 1.84 tons/ha, compared to a global average of $5.82 \mathrm{t} / \mathrm{ha}$. These findings suggest that multiple genetic and trait association investigations for newly generated maize inbred lines are still necessary, since there have been conflicting reports on the kind of gene activity regulating grain production and other agronomic parameters to push for maximum yield and variety development Maize is the primary diet in major maizeproducing areas (Mosisa et al., 2011). It accounts for roughly $16.7 \%$ of national calorie consumption, followed by sorghum (14.1\%) and wheat (12.6\%). (Guush et al., 2011). Despite its rising usage as a source of carbohydrates, maize grain, like all other cereals, is recognized for having low protein content, notably in two key amino acids, lysine and tryptophan (Sarika et $a l ., 2018)$. The absence of these two necessary amino acids, particularly in babies, may cause initial development failures such as 'kwashiorkor,' a weakened immune system, and mortality (Sultana et al., 2019). Protein deficiency is another difficulty and situation that need new approaches, particularly among youngsters who eat mostly maize and other cereal grains. The nutritional content of quality protein maize has been increased by conventional breeding, a process called as biofortification (Bouis et al., 2011). The two necessary amino acids, lysine and tryptophan, are richer in QPM varieties, resulting in a better-balanced protein for humans and other monogastric animals (Girma et al., 2010).

In Ethiopia, on the other hand, some QPM varieties that improved the nutritional quality of maize were released recently. However, due to several characteristics that have limited their adoption by farmers, such as high susceptibility to common leaf rust, especially when grown in hot spot rust; susceptibility to turcicum leaf blight; and low seed yield, the market share of these newly released varieties is generally small (Adefris et al., 2015). Furthermore, compared to normal maize, breeding for QPM varieties is a challenging task due to the QPM germplasm's low genetic basis, convoluted genetic system, and limited financing. Germplasm augmentation, genetic diversity, heritability, correlation analysis, genetic advance, and gene action investigation of the QPM inbred line, as well as further efforts via the introduction and creation of new inbred lines in Ethiopia, are required to solve these problems. Through exploitation of the genetic diversity, heritability, correlation analysis, genetic advance, and principal component available in quality protein maize and conventional maize germplasm, genetic advance of maize provides an opportunity to address some of these restrictions.

The genetic variety contained in the breeding material employed in the program is critical for a successful plant breeding program (Khan et al., 2017). When heritability is utilized to determine genetic advance (GA), which reflects the degree of gain in characteristics achieved under specific selection pressure, its usefulness improves. As a result, genetic progress is a critical selection attribute that supports the breeder in a selection procedure (Shukla et al., 2004). Information on the interrelationships between quantitatively inherited plant features and their direct and indirect consequences on grain production is critical for successful breeding program selections (Khan et al., 2006). Correlation coefficient analysis is useful in this regard since it allows for the simultaneous selection of various variables that influence yield (Menkir, 2008). Analysis of trait variability and identification of relationships between various traits that contribute to yield would aid in the development of high yielding varieties (Mary and Gopalan 2006).

Maize has been used to examine the relationship between characteristics and heritability and genetic variability (Maruthi and Jhansi Rani, 2015). Principal component analysis, on the other hand, is a multivariate approach for investigating the correlations between numerous quantitative variables (Johnson 2012). It is the most often used approach in variability research and numerical classification, and it is beneficial for grouping varieties based on their commonalities (Bello, 2004). The goal of principal component analysis is to shrink the size of the data set. PCA of morphological characterization data, according to Watson and Eyzaguirre (2002), can reveal a few key or minimal descriptors that successfully account for the majority of the variation seen, saving time and effort for future characterization attempts. The principal components technique is quite useful for finding which crop agronomic qualities contribute the most to production, and these agronomic traits should be stressed in the breeding program. PCA is a statistical approach for compressing multivariate data sets and extracting usable information. Finally, as several researchers have stated, knowing the degree of genetic diversity, heritability, and genetic progress in selection may help the breeder establish the criteria to employ for improving yield and contributing qualities (Bello et al., 2012). Because polygene controls grain yield in maize, effective yield improvement and simultaneous enhancement of yield components are essential (Reddy et al., 2013). Breeders must therefore have prior knowledge of the correct ways to examine the diversity among the available genotype in order to determine genetic heritability and others. As a result, the goal of this research is to look into the genetic variability, heritability, correlation analysis, genetic progress, and principal component analysis of yield and yield-related parameters in quality protein maize inbred lines. 


\section{Materials ANd Methods}

\section{Descriptions of experimental sites}

During the 2019 cropping season, the experiment was carried out at the Bako National Maize Research Center (BNMRC) and the Jimma Agricultural Research Center (JARC). At an altitude of 1650 meters above sea level, BNMRC is located between 9006' north latitude and 37009' east longitude in the subhumid agro-ecology. The location's mean minimum and maximum temperatures are $19.7^{\circ} \mathrm{C}$ and $22.70^{\circ} \mathrm{C}$, respectively. The site's long-term annual rainfall is 1245 $\mathrm{mm}$, with a relative humidity of 63.55 percent. The soil type of BNMRC is reddish brown in color, with a clay and loam texture (nitisols) and a pH between 6.0 and 5.9. (Girma et al., 2015). The Jimma Research Center (JARC) is located at a height of 1753 meters above sea level, between $740^{\prime} 37^{\prime} \mathrm{N}$ and $36049^{\prime} 47^{\prime} \mathrm{E}$. The average high and low temperatures are 11.9 and 26.2 degrees Celsius, respectively. It receives $1532 \mathrm{~mm}$ of rain on a yearly basis. The site's long-term yearly rainfall is 1572 $\mathrm{mm}$ per year with RH of $67 \%$. Reddish brown/ nitisols with a pH of 5.20 describe the soil type at JARC (Lemi et al., 2018).

\section{Experimental materials}

A total of $36 \mathrm{~F} 1$ hybrids and four commercial checks were used in the study. The $36 \mathrm{~F} 1$ hybrids were developed at Bako National Maize Research Center employing line by tester during the 2018/2019 cropping season from 13 parental lines ( 9 females and 4 males) brought from CIMMYT and IITA for QPM germplasm development.

\section{Experimental Design and Field Managements}

The hybrids (36F1) and four commercial checks with a total of 40 entries were planted in a $5 \times 8$ alpha lattice experimental design with three replications for both sites during the main cropping season of 2018 . Each entry was planted in one 5-meter-long row, with 0.75 -meter spacing between rows and 0.25-meter spacing between plants within a row. To guarantee excellent germination and seedling development, planting was done at the start of the major rainy season after appropriate soil moisture levels were established. Herbicide used before to emergence. Fertilizers containing NPS and urea were applied at rates of 150 $\mathrm{kg} / \mathrm{ha}$ and $250 \mathrm{~kg} / \mathrm{ha}$, respectively. The remaining agronomic practices were carried out according to the areas' recommendations.

\section{Data Collected and Data Analysis}

On a plot and sampled plant basis, data on grain yield and other significant agronomic parameters were gathered. Days to $50 \%$ silking (DS), number of ears per plant (EPP), and field weight of grain yield (GY) were collected on a plot level, while ear height $(\mathrm{EH})(\mathrm{cm})$, plant height $(\mathrm{PH})(\mathrm{cm})$, number of rows per ear (NRPE), number of kernels per row (NKPR), ear diameter (ED), ear length (EL), and thousand kernels weight (TKW) were collected on a sampled plant level (TKW). To estimate the genetic variability traits, SAS software version 9.3 (SAS Institute, 2014) was used to analyze the combined data of each hybrid class across the two sites. The phenotypic, genotypic, and environmental variations were calculated using the methods proposed by Singh and Chaundhary (1979) and Allard (1960).

\section{Estimation of variance components}

To determine genetic variability among genotypes, variance components were calculated. The anticipated mean squares of analysis of variance were used to compute error (2e), genotypic ( $2 \mathrm{~g})$, and phenotypic ( $2 \mathrm{p}$ ) variances using the method proposed by Hallauer and Miranda (1988).

Error variance $\sigma^{2} \mathrm{e}=\mathrm{MSe}$, Where: MSe= mean square of error, Genotypic variance $\sigma_{\mathrm{g}=}^{2} \frac{M s g-M s g l}{r l}$, Genotypic variance by Environment interaction variance $\sigma_{\mathrm{gl}}^{2}=\left(\frac{M s g-M s g l}{l r}\right)$ and Phenotypic variance $\sigma^{2}$ $\mathrm{p}=\sigma_{\mathrm{g}}^{2}+\left(\frac{\sigma 2 \mathrm{e}}{r l}\right)+\left(\frac{\sigma 2 \mathrm{gl}}{l}\right)$ where, MSg $=$ mean square of genotype; $\mathrm{MSgl}=$ mean square due to genotype by environment interaction; $\mathrm{MSe}=$ error mean square (mean square of environment); 1 = number of locations; $r=$ number of replications.

\section{Estimation of Coefficients of Variation}

The genotypic and phenotypic coefficients of variation were estimated according to the procedure outlined by Johnson et al. (1955) and described by Singh and Chaudhary (1985) as follows: -

$$
\mathrm{PCV}=\left(\frac{\sqrt{ } \delta 2 \mathrm{P}}{\mu}\right) \times 100, \mathrm{GCV}=\left(\frac{\sqrt{ } \delta 2 \mathrm{G}}{\mu}\right) \times 100 \text {, and }
$$
components of variance $\left(\delta^{2} \mathrm{p}, \delta^{2} \mathrm{~g}, \delta^{2} \mathrm{e}\right)$ were estimated and used for the estimation of coefficients of variation $\left(\mathrm{PCV}\right.$ and GCV): $\delta^{2} \mathrm{p}$ : phenotypic variance, $\delta^{2} \mathrm{~g}$ : genotypic variance, $\delta^{2} \mathrm{e}$ : environment variance, $\mu$ : mean value of the particular trait. PCV: phenotypic coefficient of variation, GCV: genotypic coefficient of variation. GCV and $\mathrm{PCV}$ values were categorized as low when less than $10 \%$, moderate, $10-20 \%$ and high, greater than $20 \%$ as indicated by Deshmukh et al. (1986).

\section{Heritability and genetic advance estimation}

Broad sense heritability $(\mathrm{H})$ and genetic advance (GA) for pooled data across locations for each hybrid class were estimated. Broad-sense heritability was estimated according to the procedure suggested by Singh and Chaudhary (1985):

Heritability broad sense $\left(\mathbf{H}^{2}\right)=\frac{\sigma 2 \mathrm{~g}}{\sigma 2 \mathrm{p}} \mathrm{x} 100$, Where: $\sigma^{2} \mathrm{~g}=$ genotypic variance and $\sigma^{2} \mathrm{p}=$ phenotypic variance. Then it was categorized as low (0-30\%), moderate (30-60\%) and high (>60) as indicated by Robinson et al. (1955). In other way, Singh (2001) also suggested that 
heritability percentage were categorized as low when less than $40 \%$, medium, 40-59\%,+320. moderately high, $60-79 \%$ and very high, $80 \%$.

\section{Genetic advance (GA) and genetic advance as percent of the mean (GAM) \\ $\mathrm{GA}=\left(\mathrm{K}^{*} \mathrm{p} * \mathrm{H} 2\right)$, where $\mathrm{p}$ is the phenotypic} standard deviation of the characteristics, $\mathrm{H} 2$ is the wide sense heritability estimate, and $\mathrm{k}$ is the selection differential, where $\mathrm{k}=2.063$ at $5 \%$ selection intensity. To compare the extent of predicted advances of different traits under selection, the genetic advance as a percentage of the mean was calculated. GAM $=\frac{G A}{\mu} * 100$ according to Falconer (1996) suggested, where $\mu=$ grand mean of the traits.

\section{RESULTS AND DISCUSSION}

\section{Analysis of variances}

The analysis of variance of different traits of quality protein maize is presented in Table-1. The ANOVA revealed that there were significant differences between genotypes for all of the traits studied, including grain yield, days to anthesis, days to silking, days to maturity, plant height, ear height, number of rows per ear, kernel per row, ear length, ear diameter, ear per plant, and thousand kernel weights. For all of the characteristics investigated, there were very significant (P0.01) differences across genotypes. The presence of variability in this study, according to Digvijay et al. (2020), demonstrated that there was considerable chance for selection for these characteristics. Variations across genotypes were identified owing to changes in the genes carried by various genotypes and the interaction of distinct gene combinations owned by different inbred lines with the environment to which the genotypes were exposed, which is misleading. The degree of phenotypic and genotypic variation among all eleven traits revealed that environmental factors influenced character expression. As a result, the huge amount of variation is owing to a variety of material sources as well as environmental effects, which predominately influenced the phenotypic. Plant breeders might use the genetic diversity discovered in this study to generate higher-quality protein maize hybrid cultivars. Only grain yield, kernels per row, and ear per plant showed significant GxE interaction (Table-1). Plant height, ear length, 50 percent days to anthesis, 50 percent silking, ear length, ear diameter, number of ears, number of rows per ear, number of kernels per row, ear per plant, thousand grain weight, and 100 grain weight were all observed to have high variability. In previous investigations, substantial differences between maize genotypes per row and ear per plant were found(Ghimire et al.,2015; Singh et al., 2017; Jilo et al., 2018; Beulah et al., 2018; Islam et al., 2020; Neupane et al., 2020).

Table-1: Mean squares of variance for different studied traits in maize genotypes

\begin{tabular}{|c|c|c|c|c|c|c|c|c|c|c|c|c|c|}
\hline $\begin{array}{l}\text { Source of } \\
\text { variation }\end{array}$ & DF & GY & DA & DS & MD & PH & EH & RPE & KPR & EL & ED & EPP & TKW \\
\hline $\mathrm{E}$ & 1 & $\begin{array}{l}711.04 * \\
*\end{array}$ & $\begin{array}{l}319.7 \\
* *\end{array}$ & $\begin{array}{l}75.94 \\
*\end{array}$ & $\begin{array}{l}68.2 \\
7 *\end{array}$ & 0.13 & 0.94 & $\begin{array}{l}8.36 \\
*\end{array}$ & $\begin{array}{l}6512 . \\
5 * *\end{array}$ & $\begin{array}{l}873.6 \\
4 * *\end{array}$ & $\begin{array}{l}33.09 \\
* *\end{array}$ & $\begin{array}{l}28.26 \\
* *\end{array}$ & $\begin{array}{l}0.24 * \\
*\end{array}$ \\
\hline Entry & 39 & $8.86^{* *}$ & $\begin{array}{l}21.84 \\
* *\end{array}$ & $\begin{array}{l}27.88 \\
* *\end{array}$ & $\begin{array}{l}34.8 \\
5^{*}\end{array}$ & $\begin{array}{l}1286.8 \\
3 * *\end{array}$ & $\begin{array}{l}620.9 \\
4 * *\end{array}$ & $\begin{array}{l}2.24 \\
* *\end{array}$ & $\begin{array}{l}34.15 \\
* *\end{array}$ & $3.99 *$ & $\begin{array}{l}0.22 * \\
*\end{array}$ & $\begin{array}{l}0.26^{*} \\
*\end{array}$ & $\begin{array}{l}0.006 \\
* *\end{array}$ \\
\hline GxE & 39 & $2.37 *$ & 1.06 & 0.49 & $9^{19.4}$ & 10.22 & 0.52 & 0.71 & $\begin{array}{l}20.14 \\
*\end{array}$ & $3.86^{*}$ & 0.11 & $\begin{array}{l}0.22 * \\
*\end{array}$ & 0.002 \\
\hline $\operatorname{Rep}(\mathrm{E})$ & 4 & 2.68 & 0.08 & 0.013 & $\begin{array}{l}75.3 \\
2 *\end{array}$ & 4.64 & 0.94 & 0.04 & 22.44 & $7.06 *$ & $\begin{array}{l}0.000 \\
9\end{array}$ & 0.064 & 0.004 \\
\hline Bloc(R) & 21 & 0.844 & 6.63 & 6.45 & $\begin{array}{l}55.9 \\
9 * \\
\end{array}$ & 281.28 & $\begin{array}{l}237.5 \\
6^{*} \\
\end{array}$ & 0.45 & 7.48 & 2.51 & 0.046 & 0.062 & 0.002 \\
\hline Error & 142 & 1.02 & 5.78 & 5.86 & $\begin{array}{l}16.9 \\
4\end{array}$ & 164.92 & 73.13 & 0.64 & 11.85 & 2.25 & 0.06 & 0.09 & 0.002 \\
\hline $\mathrm{Cv}$ & & 13.97 & 2.95 & 2.98 & 2.68 & 5.51 & 8.34 & 5.38 & 9.93 & 9.77 & 5.71 & 28.94 & 15.37 \\
\hline $\mathrm{R}^{2}$ & & 0.89 & 0.65 & 0.64 & 0.62 & 0.71 & 0.75 & 0.63 & 0.84 & 0.80 & 0.85 & 0.79 & 0.71 \\
\hline Root MSE & & 1.01 & 2.4 & 2.42 & 4.12 & 12.84 & 8.55 & 0.81 & 3.44 & 1.51 & 0.25 & 0.31 & 0.041 \\
\hline
\end{tabular}

*Significant at $P \leq 0.05$ level of significance, ${ }^{* *}$ Significant at $P \leq 0.01$ level of significance, $D F=$ Degree of freedom, $E=e n v i r o n m e n t$,

$C V=$ Coefficient of Variation, $G x E=$ genotype interactions with environment, $R^{2}=R$-Square, $G Y=$ grain yield, DA $=$ days to anthesis,

$D S=$ days to silking, $M D=$ days to maturity, $P H=$ plant height, $E H=$ ear height, $R P E=$ number of rows per ear, KPR=number of kernels per row, $E L=$ ear length, $E D=$ ear diameter, $E P P=$ ear per plant, $T K W=$ thousand kernel weight.

\section{Mean and range values}

The mean and ranges values for the 12 quality protein maize traits presented in Table-2.The results showed significant difference among the genotypes for grain yield and yield related traits. The mean grain yield ranged from 9.81 to 5 ton/ha. Number of kernels per row ranged from 44.73 to 34.53 with a mean value of 34.7 numbers. The range observed for kernel row per ears was 16.13 to 12.67 with overall mean of 14.8 rows. The maximum and minimum values of 1000-kernel weight were 0.41 and $0.22 \mathrm{t} / \mathrm{ha}$ respectively, with a mean value of $0.27 \mathrm{t} / \mathrm{ha}$. The mean plant and ear heights of the genotypes ranged from 263.6 to $204.3 \mathrm{~cm}$ and $123-78 \mathrm{~cm}$ with overall mean 233.1 and $102.5 \mathrm{~cm}$ respectively. The range observed for days to $50 \%$ silking was 85.8 to 77.3 days, with overall mean of 81.3 
days. Days to $50 \%$ anthesis varied from 85.7 to 77.7 , with overall mean of 81.6 days. Days to maturity varied from 159 to 147 days, with a mean of 153.7 days. Among total studied genotypes most of genotypes were showed to display early maturing day. It is, therefore, suggested that these genotypes could be used for further improvement of quality protein maize for yield and yield traits breeding approach. Mainly, the varied variability observed for grain yield as quantitatively inherent traits among the genotypes means that, there is sufficient opportunity for selection in the genotypes for improvement of these important yield traits. Tulu et al. (2014); Umar et al. (2016) and Jilo et al. (2018) reported a varied range of variability of maize attribute such as grain yield, row number per ears, number of kernels per row, ear length, ear diameter and thousandkernel weight is approved by the current study.

\section{Genetic variability (Genotypic and phenotypic coefficients of variation)}

Estimated variance components of PCV and GCV of the quality protein maize studied traits are presented in Table-3. The relative quantity of phenotypic coefficient of variation (PCV) and genotypic coefficient of variation (GCV) may be compared to obtain trustworthy and relevant information from the genuine strength of variability (GCV). The environment has a significant impact on the quantitative and qualitative characteristics of quality protein maize. Genetic qualities including genotypic coefficient of variation (GCV), heritability, phenotypic coefficient of variation (PCV), and genetic progress can be used to measure hereditary and non-heritable variation in this effect. Grain yield was shown to have a high GCV and PCA in this investigation (20.37). Grain yield showed a wide range of PCV and GCV, demonstrating that this feature is genetically controlled and highlighting the relevance of this trait in the evolution and selection of inbred lines of quality protein maize. Begum et al. (2016) found that PCV had higher amplitude of variation than GCV, suggesting that the apparent differences were not just attributable to genotypes but also to environmental variables. Ear height (14.03), ear per plant (10.50), and thousand kernel weights, on the other hand, were modest values (13.52). The remaining traits, such as rows per ear, kernels per row, ear length, days to anthesis, days to silking, and days to maturity, had low phenotypic and genotypic coefficients of variation, which could be due to phenotypic plasticity and the presence of both positive and negative alleles in the quality protein maize genotypes, resulting in low genotypic variation. Ghimire et al. (2015), Umar et al. (2016), Jilo et al. (2018), and Neupane et al., 2020 in various maize genotypes concur with the current findings. In general, the phenotypic co-efficient of variation for the traits studied was higher than the genotypic co-efficient of variation, indicating that they all interacted with the setting to some extent.

\section{Heritability and genetic advance}

Estimated heritability $\left(\mathrm{H}^{2} \%\right)$ and genetic advance of the studied traits are presented in Table-2. In order to increase the quality protein content of maize, heritability and genetic progress were shown to be critical. Incorporating genetic variation with heritability estimates would provide sufficient data on selection efficacy. Heritability is the study of how values are passed down from one generation to the next. It is the most important factor in improving the genetics of highprotein maize and other crops. Grain yield, days to anthesis, days to silking, plant and ear height, kernels per ear, ear diameter, and thousand kernels weight were all recorded for the moderate heritability; however, the low and medium heritability were only recorded for ear length and ear per plant. Kumar et al., (2014); Singh et al., 2017 and Jilo et al., 2018 were recorded similar findings in maize. Kumar and Choudhary (2018) suggested high estimates of heritability means that most of the variation is caused by genotype and very small portion attributed by environmental variations. Rocha $e t$ al. (2019) decided that heritability principles above $80 \%$ permits significant selection gains for improving grain yield of maize.

Heritability estimates alone is not appropriate as high heritability along with high GAM would be more effective. The estimated of genetic advance as percent of mean (GAM) in the present study was very high $(>20 \%)$ for grain yield, kernels per row and ear per plant. Moderate GAM values (10-20\%) for plant height, ear height and ear diameter. Agronomic attributes such as days to $50 \%$ anthesis, days to $50 \%$ silking days to maturity, number of rows per ear and ear length, showed low GAM values $(<10 \%)$. Similar results were reported for maize inbred lines by different investigators for different maize traits (Taye, 2014; Jilo et al., 2018; and Bartaula et al., 2019). On other hand, high heritability joined with high genetic advanced percent (GAM) was observed for grain yield, ear per plant and thousand kernels weight indicating the control of additive gene of action and a better prospect for selection of these attributes. Similar findings were reported by various scholars such as for grain yield (Freeman et al., 2019) and for thousand kernels weight (Rahman et al., 2017) respectively. In general, heritability is a measure of phenotypic variance attributable to genetic causes that has a predictive function in plant breeding, and the presence of large genetic variability among quality protein maize genotypes suggests that future quality protein maize improvement programs have a good chance. According to Bartaula et al. (2019), all of the characteristics investigated had substantial heritability combined with very low genetic progress as a percent of mean, indicating that the trait's expression are under the control of non-additive gene action and that its response to selection is inadequate. In this instance, the hybridization program will be fruitful. All of the other qualities tested had a high heritability combined with a 
high genetic progress, indicating that additive gene action was dominant in influencing the variables. As a result, direct selection of such features might help increase yield.

Table-2: Components of variance, coefficients of variability $(\%)$, heritability $\left(\mathrm{H}^{2}\right)$, expected genetic advance $(\mathrm{GA})$ and genetic advance as percent of mean (GAM) of maize genotypes

\begin{tabular}{|l|l|l|l|l|l|l|l|l|l|l|l|l|}
\hline Traits & Mean \pm Se & SD & Range & $\boldsymbol{\delta}_{\mathbf{p}}^{\mathbf{2}}$ & $\boldsymbol{\delta}_{\mathbf{g}}^{\mathbf{2}}$ & $\mathbf{\mathbf { \sigma } _ { \mathbf { g } }}$ & $\mathbf{P C V}$ & $\mathbf{G C V}$ & $\mathbf{H}^{\mathbf{2}} \mathbf{\%}$ & $\mathbf{G A}$ & $\mathbf{G A M} \%$ \\
\hline GY & $7.22 \pm 0.024$ & 2.7 & $9.81-5$ & 2.87 & 2.163 & 1.082 & 23.48 & 20.37 & 75.27 & 4.2 & 58.07 \\
\hline DA & $81.6 \pm 0.029$ & 4.7 & $85.7-77.7$ & 9.62 & 6.93 & 3.463 & 3.80 & 3.23 & 71.99 & 7.0 & 8.55 \\
\hline DS & $81.3 \pm 0.034$ & 4.8 & $85.8-77.2$ & 12.39 & 9.13 & 4.565 & 4.33 & 3.72 & 73.69 & 7.3 & 8.98 \\
\hline MD & $153.7 \pm 0.041$ & 12.1 & $159-147$ & 9.22 & 5.12 & 2.560 & 1.98 & 1.47 & 55.51 & 13.9 & 9.02 \\
\hline PH & $233.1 \pm 0.043$ & 27.5 & $263.6-204.3$ & 559.41 & 425.54 & 212.768 & 10.15 & 8.85 & 76.07 & 43.2 & 18.51 \\
\hline EH & $102.5 \pm 0.052$ & 12.0 & $123-78$ & 270.70 & 206.81 & 103.403 & 16.05 & 14.03 & 76.40 & 18.9 & 18.45 \\
\hline RPE & $14.8 \pm 0.053$ & 1.0 & $16.13-12.67$ & 0.74 & 0.510 & 0.255 & 5.83 & 4.83 & 68.53 & 1.4 & 9.55 \\
\hline KPR & $34.7 \pm 0.055$ & 6.8 & $44.73-34.53$ & 7.81 & 4.67 & 2.335 & 8.05 & 6.23 & 59.78 & 8.4 & 24.17 \\
\hline EL & $15.3 \pm 0.055$ & 2.7 & $19.07-15.53$ & 0.43 & 0.043 & 0.022 & 4.28 & 1.36 & 10.10 & 0.6 & 3.68 \\
\hline ED & $4.5 \pm 0.056$ & 0.5 & $5.62-4.39$ & 0.06 & 0.037 & 0.018 & 5.25 & 4.26 & 65.67 & 0.7 & 15.05 \\
\hline EPP & $1.1 \pm 0.060$ & 0.5 & $2.37-0.7$ & 0.03 & 0.013 & 0.007 & 16.18 & 10.50 & 42.11 & 0.4 & 39.48 \\
\hline TKW & $0.27 \pm 0.06$ & 0.1 & $0.41-0.22$ & 0.002 & 0.001 & 0.007 & 16.56 & 13.52 & 66.67 & 0.1 & 50.94 \\
\hline
\end{tabular}

$S D=$ standard of deviations, $S E=$ standard of error, $G Y=$ grain yield, $D A=$ days to anthesis, $D S=$ days to silking, $M D=$ days to maturity, $P H=$ plant height, EH=ear height, RPE=number of rows per ear, KPR=number of kernels per row, EL=ear length, ED=ear diameter,

$E P P=$ ear per plant, $T K W=$ thousand kernel weight, Phenotypic Variance $=\left(\sigma^{2} P\right)$ and Genotypic Variance $=\left(\sigma^{2} g\right)$, Phenotypic coefficient of variability $=(P C V)$ and Genotypic coefficient of variability $=(G C V)$, Broad sense heritability $=\left(H^{2}\right)$, Expected genetic advances $=(G A)$ and Genetic advance as percent of mean $=(G A M)$

\section{Estimates of genotypic and phenotypic correlations}

The phenotypic (upper diagonal) and genotypic (lower diagonal) correlation coefficients for all twelve quality protein maize traits were presented (Table-3).The grain yield and related traits expressed different trends of relationship among themselves. Grain yield showed highly significant positive correlations with days to maturity, plant and ear height, ear diameter, ear per plant and thousand kernels weights whereas it showed highly negative associations with the traits of days to anthesis, days to silking and number of kernels per ear correlation coefficient with grain yield. Days to anthesis and days to silking showed negative and significant correlations coefficient with plant and ear height, number of kernels per row, ear diameter, ear length and thousand kernels weight. Positive significant correlation was found in plant height, ear height, number of kernels per row, ear length, ear diameter, ear per plant and thousand kernels weight with yield at genotypic levels. According to Rocha et al., (2019) suggested if the relationship is owing to indirect effect of the trait through another trait, then corn breeder must select latter trait / traits contributing indirectly to enhance grain yield. On other hand, Alhussein and Idris (2017) reported that selection of negative and indirect effects would lead towards low efficiency for improving end trait. Selection of indirect and positive component traits i.e., no. of grains and no. of kernel rows for increasing kernel weight are beneficial. Wise indirect selection based on path coefficient analysis would impart faster genetic improvement of maize hybrids.

Table-3: Phenotypic correlation coefficients of different traits among twelve maize genotypes

\begin{tabular}{|c|c|c|c|c|c|c|c|c|c|c|c|c|}
\hline Variable & GY & DA & DS & MD & PH & EH & RPE & KPR & EL & ED & EPP & TKW \\
\hline GY & 1 & $-0.65 * *$ & $-0.66 * *$ & $0.158 *$ & $0.742 * *$ & $0.530 * *$ & $-0.13^{*}$ & $0.701 * *$ & $0.639 * *$ & $0.675 * *$ & $0.762 * *$ & $0.444 * *$ \\
\hline DA & $-0.65 * *$ & 1 & $0.98 * *$ & 0.02 & $-0.51 * *$ & $-0.18^{*}$ & $0.24 *$ & $-0.64^{*}$ & $-0.61 *$ & $-0.59 *$ & $-0.51 *$ & $-0.38 *$ \\
\hline DS & $-0.66^{* *}$ & $0.98 *$ & 1 & 0.02 & $-0.53 * *$ & $-0.19 *$ & $0.24 *$ & $-0.65^{*}$ & $-0.62 *$ & $-0.58 * *$ & $-0.52 * *$ & $-0.38 * *$ \\
\hline MD & $0.16^{*}$ & 0.02 & 0.02 & 1 & $0.23^{*}$ & $0.25^{* *}$ & $0.13 *$ & 0.07 & 0.11 & $0.16^{*}$ & 0.08 & $0.18 *$ \\
\hline $\mathbf{P H}$ & $0.74 * *$ & $-0.51 * *$ & $-0.53 * *$ & $0.23 *$ & 1 & $0.74 * *$ & -0.11 & $0.67 * *$ & $0.61 * *$ & $0.64 * *$ & $0.66^{* *}$ & $0.49 * *$ \\
\hline EH & $0.53 * *$ & $-0.18 *$ & $-0.19 *$ & $0.25 * *$ & $0.74 * *$ & 1 & 0.07 & $0.38 * *$ & $0.37 * *$ & $0.49 * *$ & $0.42 * *$ & $0.41 * *$ \\
\hline RPE & $-0.133^{*}$ & $0.24 *$ & $0.24 *$ & 0.13 & -0.11 & 0.07 & 1 & $-0.19 *$ & $-0.19 *$ & -0.06 & $-0.13^{*}$ & $-0.19 *$ \\
\hline KPR & $0.70^{* *}$ & $-0.64 * *$ & $-0.65 * *$ & 0.07 & $0.67 * *$ & $0.38 * *$ & $-0.19 *$ & 1 & $0.74 * *$ & $0.63 * *$ & $0.61 * *$ & $0.44 * *$ \\
\hline EL & $0.64 * *$ & $-0.61 * *$ & $-0.62 * *$ & 0.11 & $0.61 * *$ & $0.37 * *$ & $-0.19^{*}$ & $0.74 * *$ & 1 & $0.64 * *$ & $0.49 * *$ & $0.49 * *$ \\
\hline ED & $0.68 * *$ & $-0.59 * *$ & $-0.58 * *$ & $0.16^{*}$ & $0.64 * *$ & $0.49 * *$ & -0.06 & $0.63 * *$ & $0.64 * *$ & 1 & $0.56 * *$ & $0.61 * *$ \\
\hline EPP & $0.76 * *$ & $-0.51 * *$ & $-0.52 * *$ & 0.08 & $0.66 * *$ & $0.42 * *$ & $-0.13^{*}$ & $0.61 * *$ & $0.49 * *$ & $0.59 * *$ & 1 & $0.34 * *$ \\
\hline TKW & $0.44 * *$ & $-0.38 * *$ & $-0.38 * *$ & $0.18 *$ & $0.49 * *$ & $0.41 * *$ & $-0.19 *$ & $0.44 * *$ & $0.49 * *$ & $0.61 * *$ & $0.34 * *$ & 1 \\
\hline
\end{tabular}

Correlation Coefficients / $\mathrm{Pr}>|\mathrm{r}|$, **Significant at $\mathrm{P} \leq 0.01$ level of significance, *Significant at $\mathrm{P} \leq 0.05$ level of significance, $\mathrm{GY}=$ grain yield, $\mathrm{DA}=$ days to anthesis, $\mathrm{DS}=$ days to silking, $\mathrm{MD}=$ days to maturity, $\mathrm{PH}=$ plant height, $\mathrm{EH}=$ ear height, $\mathrm{RPE}=$ number of rows per ear, $\mathrm{KPR}=$ number of kernels per row, $\mathrm{EL}=$ ear length, $\mathrm{ED}=$ ear diameter, $\mathrm{EPP}=$ ear per plant, $\mathrm{TKW}=$ thousand kernel weight.

\section{Principal component analysis (PCA)}

The principal component analysis, eigenvalue, Variance contribution and Cumulative variance of the studied quality protein maize traits are presented in
Table-4. The analysis of variance for 36 inbred lines and four commercial checks of maize for twelve quantitative traits displayed significant differences between the inbred lines for the traits considered 
indicating an existence of considerable expanse of genetic variability in the investigated material. Principal component analysis is an important breeding instrument commonly used by breeders to identify traits that could be used to select crop genotypes. Analysis of variability among traits contributing to yield would be of great importance in planning a successful breeding program (Johnson, 2012). The genetic diversity in 36 advance quality protein maize inbred line including four checks were observed for grain yield and yield related component traits for the selection of high yielding of quality protein maize genotypes for further breeding programs.

The twelve components which had eigen values equal to or greater than one was engaged as meaningful interpretation (Table-4). The principal component analysis indicated that the first principal component (PC1) had an eigenvalue of 6.16 and reflects 4.60 of the total difference. The PC7 showed high weights in ear per plant (EPP) and probably reflecting yield. The second and fifth principal component (PC2 and PC5) kernel rows per ear (KRPE) had the largest weight, thus reflecting yield. The tenth and the second principal component (PC10 and PC2) showed high value on yield per hectare (t/ha). Eighth principal component (PC8) had a weighted high value of plant height $(\mathrm{PH})$; this is probably reflecting the plant structure. Furthermore, the twelfth principal component (PC12) recorded the highest value on Days to silking (DS), thus reflecting silking development.

The first principal component explained 51\% of the total phenotypic variation proportions and cumulative variance with the main contribution from twelve traits. Principal component two accounted for $64 \%$ of the total cumulative variance with traits including days to silking, days to anthesis, days to maturity, ear height and number of kernels per ear contributing the most to this component. Similarly, reported the important contribution of the first PCs in the total variability while studying various traits. Principal component analysis usually used in plant sciences for the reduction of variables and grouping of maize genotypes (Mujaju et al., 2008; Ali et al., 2011). Several authors reported first principal component (PC) scores as contribution traits for the clustering process (Mujaju et al.,2008; Solomon, 2021). Maruthi and Rani (2015) observed the principal component analysis revealed that in major vector-I, the important characters responsible for genetic divergence in the major axis of differentiation were grain yield, plant height, ear height, ear length, kernel rows/ear, kernels/row and 100 kernel weights. On other hand, Patel et al., 2020 reported the principal component analysis identified six principal components (PCs) with Eigen value greater than one and accounted for 76.25 per cent of the overall variability among the maize genotypes. And observed the contribution of PC1 was found to be 25.99 per cent in the total divergence of the studied population, in which the major contributing traits were ear height, plant height, grain weight per plant, ear diameter and ear length. Mounika et al. (2018) observed the PCA identified four principal components (PCs) with Eigen value greater than 1.00 and accounted for 80.35 per cent of total variation.

Table-4: Eigenvalue analysis, Eigen Vectors, and Contribution of variables in total variability (PC1 to PC12) of maize genotypes.

\begin{tabular}{|l|l|l|l|l|l|l|l|l|l|l|l|l|l|}
\hline \multicolumn{1}{|l}{ Eigenvectors } \\
\hline Traits & PC1 & PC2 & PC3 & PC4 & PC5 & PC6 & PC7 & PC8 & PC9 & PC10 & PC11 & PC12 \\
\hline GY & 0.35 & 0.05 & -0.14 & 0.11 & -0.21 & -0.10 & 0.16 & -0.05 & 0.24 & 0.81 & 0.21 & 0.02 \\
\hline DA & -0.32 & 0.36 & 0.18 & 0.28 & 0.01 & 0.28 & 0.26 & -0.03 & -0.02 & 0.09 & 0.10 & -0.70 \\
\hline DS & -0.32 & 0.35 & 0.18 & 0.27 & 0.02 & 0.26 & 0.27 & -0.10 & -0.01 & 0.05 & 0.10 & 0.71 \\
\hline MD & 0.07 & 0.49 & 0.22 & -0.70 & -0.46 & 0.01 & 0.04 & -0.01 & -0.04 & -0.03 & -0.06 & 0.00 \\
\hline PH & 0.34 & 0.24 & 0.02 & 0.22 & -0.13 & -0.02 & -0.28 & 0.14 & -0.10 & -0.32 & 0.74 & 0.00 \\
\hline EH & 0.24 & 0.49 & 0.05 & 0.37 & 0.04 & -0.10 & -0.52 & -0.06 & 0.04 & 0.05 & -0.53 & 0.01 \\
\hline NRPE & -0.09 & 0.41 & -0.77 & -0.20 & 0.38 & 0.02 & 0.08 & 0.20 & 0.05 & -0.02 & 0.04 & 0.00 \\
\hline NKPR & 0.34 & -0.09 & -0.06 & 0.02 & -0.03 & 0.52 & 0.09 & 0.29 & -0.68 & 0.14 & -0.18 & 0.03 \\
\hline EL & 0.32 & -0.07 & 0.05 & -0.12 & 0.14 & 0.67 & -0.05 & -0.07 & 0.61 & -0.16 & -0.04 & -0.01 \\
\hline ED & 0.33 & 0.09 & 0.01 & -0.09 & 0.34 & -0.08 & 0.22 & -0.79 & -0.27 & -0.08 & 0.06 & -0.05 \\
\hline EPP & 0.31 & 0.03 & -0.18 & 0.30 & -0.36 & -0.19 & 0.59 & 0.10 & 0.14 & -0.41 & -0.25 & -0.01 \\
\hline TKW & 0.25 & 0.12 & 0.49 & -0.11 & 0.56 & -0.27 & 0.26 & 0.45 & 0.07 & 0.05 & 0.00 & 0.01 \\
\hline Eigenvalue & 6.16 & 1.56 & 0.92 & 0.82 & 0.70 & 0.49 & 0.46 & 0.29 & 0.24 & 0.19 & 0.15 & 0.02 \\
\hline Difference & 4.60 & 0.64 & 0.10 & 0.12 & 0.21 & 0.03 & 0.18 & 0.04 & 0.05 & 0.04 & 0.13 & \\
\hline Proportion & 0.51 & 0.13 & 0.08 & 0.07 & 0.06 & 0.04 & 0.04 & 0.02 & 0.02 & 0.02 & 0.01 & 0.00 \\
\hline Cumulative & 0.51 & 0.64 & 0.72 & 0.79 & 0.85 & 0.89 & 0.93 & 0.95 & 0.97 & 0.99 & 1.00 & 1.00 \\
\hline
\end{tabular}

\section{SuMMARY AND CONCLUSION}

For all of the variables evaluated in this study, there were highly significant (P0.01) differences between genotypes, indicating that there are plenty of genetic variations between genotypes. The disparity in magnitude of phenotypic and genotypic variation among all eleven characteristics suggested that the environment played a role in character expression. As a result, the huge amount of variation is owing to a variety of material sources as well as environmental 
effects, which predominately influenced the phenotypic. The average grain yield was 9.81 to 5 tons per hectare. The number of kernels each row varied from 44.73 to 34.53 , with an average value of 34.7. The environment has a significant impact on the quantitative and qualitative characteristics of quality protein maize. Genetic qualities including genotypic coefficient of variation (GCV), heritability, phenotypic coefficient of variation (PCV), and genetic progress can be used to measure hereditary and non-heritable variation in this effect. Grain yield was shown to have a high GCV and PCA in this investigation (20.37).

Grain yield showed a wide range of PCV and $\mathrm{GCV}$, demonstrating that this feature is genetically controlled and highlighting the relevance of this trait in the evolution and selection of inbred lines of quality protein maize. Heritability values were found to be high for several of the qualities investigated, but genetic progress was found to be low to moderate, indicating that non-additive gene activity was influencing the manifestations of these features. As a result, selection is recommended to be put on hold because to future segregating generations. On the other hand, in this study, the estimated genetic advance as a percent of mean (GAM) for grain production, kernels per row, and ear per plant was quite high (>20 percent). Plant height, ear height, and ear diameter have moderate GAM values (10-20\%). Low GAM values (less than 10\%) were detected in agronomic variables such as days to $50 \%$ anthesis, days to $50 \%$ silking, days to maturity, number of rows per ear, and ear length. Days until anthesis, silking, maturity, plant height, ear height, number of rows per ear, kernel per row, ear length, ear diameter, ear per plant, and thousand kernel weights were all shown to have extremely significant genotypic and phenotypic associations with grain yield in this study. These qualities had a positive direct and indirect influence on the other attributes as well. As a result, these features might be used as major selection criteria in maize breeding programs to boost grain output.

For most characteristics, larger genotypic correlation values were detected than their corresponding phenotypic correlation, indicating that the clearly observable linkages may be mostly owing to intrinsic trait relationships and a low modifying influence of environment on trait association. As a result, a substantial and positive association between grain yield and other qualities has been established, providing a dependable and important chance to increase grain yield and yield-related traits at the same time. The first principle component (PC1) has an eigenvalue of 6.16 and represents 4.60 of the overall difference, according to the principal component analysis. Grain yield and other yield-related variables that may impact productivity of grain yield and quality factors can be used to choose promising quality protein maize genotypes. As a conclusion, in future quality protein maize breeding efforts, special attention and emphasis should be given to yield and quality attributing characteristics in order to increase yield and quality attributes. Further investigation of these and other genotypes at several locations and across time is recommended to confirm the positive outcomes found in this study and to get more valuable and reliable results. Finally, it is possible that the information gathered during this analysis will be invaluable to researchers working to develop high-yielding, highquality protein maize types.

\section{Conflict of Interests}

The authors have not acknowledged any conflict of interests.

\section{ACKNOWLEDGMENTS}

The authors are grateful to EIAR for their financial assistance. The authors would also want to express their gratitude to all maize research employees at Bako national maize research center and Jimma agricultural research center for their help in field trail monitoring, assessment, and data collection. We appreciate everything they have done.

\section{Reference}

- Abate, T., Shiferaw, B., Menkir, A., Wegary, D., Kebede, Y., Tesfaye, K., ... \& Keno, T. (2015). Factors that transformed maize productivity in Ethiopia. Food security, 7(5), 965-981.

- Alhussein, M. B., \& Idris, A. E. (2017). Correlation and path analysis of grain yield components in some maize (Zea mays L.) genotypes. International Journal of Advanced Researcha Publications, 1(1), 79-82.

- Ali, M. A., Jabran, K., Awan, S. I., Abbas, A., Zulkiffal, M., Acet, T., ... \& Rehman, A. (2011). Morpho-physiological diversity and its implications for improving drought tolerance in grain sorghum at different growth stages. Australian Journal of crop science, 5(3), 311-320.

- $\quad$ Allard, R. W. (1960). Principles of Plant Breeding. John Wiley and Sons. Inc., New York.

- Bartaula, S., Panthi, U., Timilsena, K., Acharya, S. S., \& Shrestha, J. (2019). Variability, heritability, and genetic advance of maize (Zea mays L.) genotypes. Research in Agriculture Livestock and Fisheries, 6(2), 163-169.

- Begum, S., Ahmed, A., Omy, S. H., Rohman, M. M., \& Amiruzzaman, M. (2016). Genetic variability, character association and path analysis in maize (Zea mays L.). Bangladesh Journal of Agricultural Research, 41(1), 173-182.

- Bello, D. (2004). "Genetic variability and interrelationship of traits in local sorghum (Sorghum bicolor (L.) Moench) in adamawa state." unpublished M.Sc. Thesis, Yola: Federal University of Technology. 
- Bello, O., Ige, S., Azeez, M., Afolabi, M., Abdulmaliq, S., \& Mahamood, J. (2012). Heritability and genetic advance for grain yield and its component characters in maize (Zea mays L.). International Journal of Plant Research, 2(5), 138145 .

- Beulah, G., Marker, S., \& Rajasekhar, D. (2018). Assessment of quantitative genetic variability and character association in maize (Zea mays L.). $J$ Pharmacogn Phytochem, 7, 2813-2816.

- Bouis, H. E., Hotz, C., McClafferty, B., Meenakshi, J. V., \& Pfeiffer, W. H. (2011). Biofortification: a new tool to reduce micronutrient malnutrition. Food and nutrition bulletin, 32(1_suppl1), S31-S40.

- Deshmukh, S. N., Basu, M. S., \& Reddy, P. S. (1986). Genetic variability, character association and path coefficients of quantitative traits in Virginia bunch varieties of groundnut. Indian Journal of Agricultural Sciences.

- Falconer, D.S., Mackay, F.C. (1996). Introduction to Quantitative Genetics. Longman, New York P 464.

- FAO, FAOSTAT. (2019). Food and agriculture organization of the United Nations, Rome, Italy.

- Ghimire, B., Timsina, D., \& Nepal, J. (2015). Analysis of chlorophyll content and its correlation with yield attributing traits on early varieties of maize (Zea mays L.). Journal of Maize Research and Development, 1(1), 134-145.

- Guush, B., Zelekawork, P., Kibrom, T., \& Seneshaw, T. (2011). Food grain consumption and calorie intake patterns in Ethiopia. Ethiopia strategy support program II, Ethiopia, working paperno, 23.

- Hallauer, A.R., Miranda, J.B. (1988). Quantitative genetics in maize breeding. 2nd ed. Iowa state Universality Press.

- Hosana, G. C., Alamerew, S., Tadesse, B., \& Menamo, T. (2015). Test cross performance and combining ability of maize (Zea mays L.) inbred lines at Bako, Western Ethiopia. Global $J$. INC.(USA), 15(4), 24.

- Islam, S., Ferdausi, A., Sweety, A. Y., Das, A., Ferdoush, A. and Haque, M. A. (2020). Morphological characterization and genetic diversity analyses of plant traits contributed to grain yield in maize (Zea mays L.). Journal of Bioscience and Agriculture Research, 25(01), 2047-2059.

- Jilo, T., Tulu, L., Birhan, T., \& Beksisa, L. (2018). Genetic variability, heritability and genetic advance of maize (Zea mays L.) inbred lines for yield and yield related traits in southwestern Ethiopia. Journal of Plant Breeding and Crop Science, 10(10), 281-289.

- Johnson, D. E. (2012). Applied multivariate methods for data analysis. New York: Duxbury Press.
- Johnson, D.E. (2012). Applied Multivariate Methods for Data Analysis. New York: Duxbury Press.

- Johnson, H. W., Robinson, H. F., \& Comstock, R. E. (1955). Estimates of genetic and environmental variability in soybean. Agronomy Journal, 473, 14318.

- Katragadda, S., Tekale, P., \& Dinasarapu, S. (2020). Identification of potential parental lines for single, three-way and double crosses in maize (Zea mays L.). Maydica, 65(2), 9.

- Khan, F. A., Ali, S., Shakeel, A., Saeed, A., \& Abbas, G. (2006). Genetic variability and genetic advance analysis for some morphological traits in (Brassica napus L.). J. Agric. Res, 44(2), 83-88.

- Khan, S. A., \& Hassan, G. (2017). Heritability and correlation studies of yield and yield related traits in bread wheat. Sarhad Journal of Agriculture, 33(1), 103-107.

- Kumar, P.G., Reddy, N.V., Kumar, Sudheer. and Rao, V.P. (2014). Genetic variability, heritability, and genetic advance studies in newly developed maize genotypes (Zea mays L.). International Journal of pure and applied Bioscience, 2(1) 272275.

- La Rovere, R. K., Abdoulaye, G., Dixon, T., Mwangi, J., Guo, W. M., \& Z Banziger, M. (2010). Potential impact of investments in drought tolerant maize in Africa. CIMMYT.

- Legesse, W., Mosisa, W., Berhanu, T., Girum, A., Wende, A., Solomon, A., ... \& Belayneh, A. (2011). Genetic improvement of maize for midaltitude and lowland sub-humid agro-ecologies of Ethiopia. In Meeting the Challenges of Global Climate Change and Food Security through Innovative Maize Research (p. 24).

- Makore, F., Gasura, E., Souta, C. M., Mazarura, U., Derera, J., Zikhali, M., ... \& Dari, S. (2021). Molecular characterization of a farmer-preferred maize landrace population from a multiple-stressprone subtropical lowland environment.

- Maruthi, R. T., \& Rani, K. J. (2015). Genetic variability, heritability and genetic advance estimates in maize (Zea mays L.) inbred lines. Journal of Applied and Natural Science, 7(1), 149-154.

- Maruthi, R. T., \& Rani, K. J. (2015). Genetic variability, heritability and genetic advance estimates in maize (Zea mays L.) inbred lines. Journal of Applied and Natural Science, 7(1), 149-154.

- Mary, S. S., \& Gopalan, A. (2006). "Dissection of genetic attributes yield traits of fodder cowpea in F3 and F4." Journal Applications Sciences Researcher, 2(6); 805-08.

- Mengistu, S. (2021). Maize Germplasm Characterization Using Principal Component and Cluster Analysis. American Journal of BioScience, 9(4), p.122. 
- Menkir, A. (2008). Genetic variation for grain mineral content in tropical-adapted maize inbred lines. Food chemistry, 110(2), 454-464.

- Mounika, K., Ahamed, M. L., \& Nafeez, U. S. (2018). Principal component and cluster analysis in inbred lines of maize (Zea mays L.). Int. J. Curr. Microbiol. App. Sci, 7(06), 3221-3229.

- Mujaju, C., \& Chakauya, E. (2008). Morphological variation of sorghum landraces from semi-arid areas of Zimbabwe.

- Muliadi, A., Effendi, R., \& Azrai, M. (2021, February). Genetic variability, heritability and yield components of waterlogging-tolerant hybrid maize. In IOP Conference Series: Earth and Environmental Science (Vol. 648, No. 1, p. 012084). IOP Publishing.

- Neupane, B., Poudel, A., \& Wagle, P. (2020). Varietal evaluation of promising maize genotypes in mid hills of Nepal. Journal of Agriculture and Natural Resources, 3(2), 127-139. CrossRef.

- Patel, N., Patel, J. M., Patel, J. A., Parmar, L. D., Thakor, D. M., Patel, S. K., \& Patel, C. R. (2020). Genetic diversity study for useful breeding traits in maize inbred lines using principle component and cluster analysis grown under rainfed condition.

- Prasanna, B.M. (2012). Diversity in global maize germplasm: characterization and utilization. $J$ Biosci, 37(5); 843-855.

- Rahman, M., Hoque, A., Amir Hossain, M., \& Abdullah Al Bari, M. (2017). Variability and Traits Association Analyses in Maize (Zea mays L.) Genotypes. The Agriculturists, 15(2), 101-114.

- Ravindra, K., \& Karan, C. (2018). Variability, heritability, character association and path analysis in maize (Zea mays L.). Agriways, 6(1), 1-8.

- Reddy, V. R., Jabeen, F., Sudarshan, M. R., Rao, A. S., \& Mays, L. (2013). Studies on genetic variability, heritability, correlation, and path analysis in maize (Zea may L.) over locations.

- $\quad$ Rocha, R. S., Nascimento, M. R., Chagas, J. T. B., de Almeida, R. N., dos Santos, P. R., da Cruz, D. P., ... \& Daher, R. F. (2019). Association among Agro-morphological Traits by Correlations and Path in Selection of Maize Genotypes. Journal of Experimental Agriculture International, 1-12.

- Sarika, K., Hossain, F., Muthusamy, V., Zunjare, R. U., Baveja, A., Goswami, R., ... \& Gupta, H. S. (2018). Marker-assisted pyramiding of opaque2 and novel opaque16 genes for further enrichment of lysine and tryptophan in sub-tropical maize. Plant Science, 272, 142-152.

- Shukla, S., Bhargava, A., Chatterjee, A., \& Singh, S. P. (2004). Estimates of genetic parameters to determine variability for foliage yield and its different quantitative and qualitative traits in vegetable amaranth (A. tricolor)[India]. Journal of Genetics and Breeding (Italy).

- Singh, D., Kumar, A., Kumar, R., Kushwaha, N., Mohanty, T. A., \& Kumari, P. (2020). Genetic variability analysis of QPM (Zea mays L.) inbreds using morphological characters. International Journal Current Microbiology Applied Science, 9(2), 328-338.

- $\quad$ Singh, G., \& Kumar, R. (2017). Genetic parameters and character association study for yield traits in maize (Zea mays L.). Journal of Pharmacognosy and Phytochemistry, 6(5), 808-813.

- Singh, R. K., \& Chaudhary, B. D. (1977). Biometrical methods in quantitative genetic analysis. Biometrical methods in quantitative genetic analysis.

- Singh, R. K., \& Chaudhary, B. D. (1985). Biometrical method in quantitative genetic analysis. Kalyani Publishers, Ludhiana, New Delhi, 54-57.

- Sultana, R., Jamil, S., Aslam, M., Shahzad, R., Fatima, R., Maqbool, M. A., \& Iqbal, M. Z. (2019). Overview of quality protein maize and molecular breeding approaches for its development. International Journal of Biosciences, 14, 533-542.

- $\quad$ Taye, A. F. (2014). Genetic variability of yield and yield related traits in some maize inbred lines (Zea mays L.) developed for mid-altitude agro-ecology of Ethiopia (Doctoral dissertation, MSc thesis submitted to the collage of Natural and Computational Sciences, Department of Biology, School of Graduate Studies, Haramaya University).

- Teklewold, A., Gissa, D. W., Tadesse, A., Tadesse, B., Bantte, K., Friesen, D., \& Prasanna, B. M. (2015). Quality Protein Maize (QPM): A guide to the technology and its promotion in Ethiopia.

- Tulu, B. N. (2014). Correlation and path coefficients analysis studies among yield and yield related traits of quality protein maize (QPM) inbred lines. International Journal of Plant Breeding and Crop Science, 1(2), 006-017.

- Umar, U. U., Abdulrahman, M. D., \& Abdullahi, S. (2016). Assessment of genetic variability of maize inbred lines and their hybrids under normal and drought conditions. Nigeria Agricultural Journal, 46(2), 82-88.

- Watson, J. W., \& Eyzaguirre, P. B. (Eds.). (2002). Home gardens and in situ conservation of plant genetic resources in farming systems. Bioversity International.

Cite This Article: Lemi Yadesa et al (2021). Genetic Variability, Heritability, Correlation Analysis, Genetic advance, and Principal Component Analysis of Grain Yield and Yield Related Traits of Quality Protein Maize (Zea mays L) Inbred lines Adapted to Mid-altitude Agroecology of Ethiopia. EAS J Nutr Food Sci, 4(1), 8-17. 